Katarzyna Lach

Zaakceptowany: 14.05.2020

Uniwersytet Ekonomiczny w Krakowie

\title{
Efekt dźwigni finansowej a struktura źródel finansowania przedsiębiorstw w Polsce w latach 2005-2018
}

\author{
THE FINANCIAL LEVERAGE EFFECT AND THE \\ SOURCES OF FINANCING FOR ENTERPRISES IN \\ POLAND FROM 2005-2018
}

Mechanizm dźwigni finansowej należy do podstawowych zagadnień zarzqdzania finansami przedsiębiorstwa, a dokładniej kształtowania struktury źródel finansowania. Literatura poświęca temu zjawisku sporo uwagi, ale przede wszystkim od strony teoretycznej. Niewiele jest jednak badań empirycznych, $w$ których zbadane by było czy mechanizm i efekt dźwigni finansowej jest znany $i$ wykorzystywany przez praktyków.

Celem niniejszego artykułu jest analiza racjonalności decyzji o stopniu zaangażowania kredytów i pożyczek $w$ finansowaniu przedsiębiorstw z punktu widzenia efektu dźwigni finansowej. Analizq objęto lata 2005-2018, zbadano czy przedsiębiorstwa $w$ Polsce mialy możliwość wykorzystywania dlugu do zwiększania rentowności kapitałów własnych oraz sprawdzono czy decyzje o zaciaganiu kredytów i pożyczek byly skorelowane z poziomem nadwyżki rentowności operacyjnej aktywów nad oprocentowaniem długu, co jest warunkiem pozytywnego efektu dźwigni finansowej.

Wykazane zostało, że w większości badanych lat przedsiębiorstwa mogły podwyższać osiagane stopy zwrotu z kapitatów własnych poprzez zwiększanie udziału dlugu $w$ finansowaniu, nie stwierdzono jednak, aby decyzje te były podejmowanie przy uwzględnianiu zjawiska i efektu dźwigni finansowej.

Słowa kluczowe: dźwignia finansowa, źródła finansowania, struktura kapitału.

JEL Codes: G30, G32.

\section{Wstęp}

Dyskusja na temat struktury źródeł finansowania trwa od początku prowadzenia rozważań nad zarządzaniem finansami przedsiębiorstw. Decyzje o finansowaniu spełniają kluczową rolę w zarządzaniu każdym podmiotem gospodarczym. Głównym celem finansowania jest oczywiście zapewnienie funkcjonowania przedsiębiorstwa, ale ostatecznie cel ten powinien być zbieżny z najważniejszym celem działalności, którym jest maksymalizacja jego wartości, co jest rozumiane jako maksymalizacja bogactwa jego właścicieli. Wprawdzie w praktyce uznaje się, że cel ten jest realizowany poprzez zwiększanie wartości wypłacanej dywidendy oraz wzrost wartości akcji (udziałów) w przedsiębiorstwie. Można jednak również uznać, że na maksymalizację bogactwa właścicieli zasadniczy wpływ ma rentowność (stopa zwrotu) z wniesionych przez nich 
kapitałów (ROE). Rentowność ta uzależniona jest oczywiście od wysokości przychodów i kosztów operacyjnych, ale wpływ na nią mają także koszty finansowe generowane przez oprocentowane kapitały obce zaangażowane w finansowaniu działalności oraz sama struktura źródeł finansowania.

Celem niniejszego opracowania jest zaprezentowanie praktycznego ujęcia zjawiska i efektu dźwigni finansowej oraz analiza racjonalności decyzji o stopniu zaangażowania kredytów i pożyczek w finansowaniu przedsiębiorstw z punktu widzenia wpływu na rentowność kapitałów własnych.

Artykuł składa się z kilku części. W pierwszej dokonano syntetycznej prezentacji pojęcia dźwigni finansowej i jej efektu w oparciu o przegląd literatury. Zaprezentowano także warunek uzyskiwania dodatniego efektu dźwigni. Kolejne punkty są już empiryczną weryfikacją możliwości uzyskiwania przez firmy w Polsce pozytywnego efektu dźwigni finansowej oraz prezentacją zakresu wykorzystywania kredytów i pożyczek w finansowaniu przedsiębiorstw w latach 2005-2018. W ostatniej części za pomocą analizy korelacji zbadano czy udział dłużnych kapitałów zwiększał się wraz z pojawianiem się możliwości uzyskiwania pozytywnego efektu dźwigni finansowej, czyli zjawiska zwiększającego rentowość kapitałów wniesionych przez właścicieli.

\section{Zjawisko oraz efekt dźwigni finansowej}

Dźwignia finansowa to pojęcie towarzyszące ekonomistom od co najmniej kilkudziesięciu lat. W tym czasie powstały różne jej definicje, ujęcia, sposoby wykorzystania. Należy przy tym podkreślić, że pojęciu dźwigni finansowej towarzyszy wiele nieścisłości teoretycznych, co prowadzi do swoistego chaosu pojęciowego. Słowo leverage $\mathrm{w}$ języku angielskim oznacza zarówno dźwignię, jak i zadłużenie oraz jego skutki, co może prowadzić do błędnego tłumaczenia i rozumienia anglojęzycznych opracowań, a także do nieprecyzyjnego definiowania i wykorzystania pojęć takich jak sama ,dźwignia finansowa” czy „efekt dźwigni finansowej”.

Pojęcie dźwigni finansowej wiąże się niewątpliwie $\mathrm{z}$ finansowaniem przedsiębiorstwa, a więc zapewnieniem mu kapitału. Na kapitał przedsiębiorstwa składa się kapitał własny, jak i obcy. Zjawisko dźwigni finansowej związane jest z wykorzystywaniem oprocentowanego kapitału obcego do uzyskiwania korzyści finansowych w postaci zwiększenia rentowności kapitału własnego.

W literaturze przedmiotu dźwignia finansowa rozumiana jest bardzo różnie. W poniższej Tabeli 1 zostały zestawione wybrane sposoby rozumienia tego pojęcia prezentowane przez różnych autorów.

W podejściach zaprezentowanych powyżej zauważyć można generalnie trzy ujęcia dźwigni finansowej:

1. utożsamianie dźwigni finansowej z finansowaniem kapitałem obcym,

2. utożsamianie dźwigni finansowej $\mathrm{z}$ miarą zmienności wyniku finansowego netto przedsiębiorstwa względem zmian wyniku operacyjnego,

3. utożsamianie dźwigni finansowej $\mathrm{z}$ mechanizmem zwiększania rentowności kapitału własnego poprzez wykorzystanie kapitału obcego w finansowaniu przedsiębiorstwa.

W niniejszym opracowaniu dźwignia finansowa rozpatrywana będzie według ujęcia trzeciego. 
Tabela 1. Wybrane definicje dźwigni finansowej

\begin{tabular}{|c|c|}
\hline Autor & Definicja \\
\hline T. Berent & $\begin{array}{l}\text { Przez dźwignię finansową rozumie się wpływ działalności finansowej przedsiębiorstwa } \\
\text { na jego wyniki finansowe, polegający na ,wzmocnieniu” znaków wyników operacyjnych, } \\
\text { tak że dodatnie wyniki operacyjne stają się bardziej dodatnie na poziomie netto, a ujemne } \\
\text { stają się bardziej ujemne. }\end{array}$ \\
\hline $\begin{array}{l}\text { Z. Bodie, } \\
\text { R. C. Merton }\end{array}$ & Dźwignia finansowa oznacza po prostu użytkowanie pożyczonych pieniędzy. \\
\hline $\begin{array}{l}\text { E. F. Brigham, } \\
\text { J. F. Houston }\end{array}$ & Stopień w jakim firma finansuje się poprzez zaciagganie pożyczek. \\
\hline $\begin{array}{l}\text { J. Czekaj, } \\
\text { Z. Dresler }\end{array}$ & $\begin{array}{l}\text { Zjawisko dźwigni finansowej polega na wykorzystaniu struktury kapitału do zwiększenia } \\
\text { siły zarobkowej kapitału własnego. }\end{array}$ \\
\hline W. Dębski & $\begin{array}{l}\text { Wprowadzenie kapitału obcego do struktury źródeł finansowania przedsiębiorstwa lub też } \\
\text { zwiększenie jego udziału w tej strukturze powoduje zwiększenie tzw. siły zarobkowej } \\
\text { kapitału własnego, co określa się mianem dźwigni finansowej. }\end{array}$ \\
\hline A. Duliniec & $\begin{array}{l}\text { Zaciaganie przez przedsiębiorstwo oprocentowanych zobowiązań uruchamia mechanizm } \\
\text { tzw. dźwigni finansowej. Jej głównym celem jest podwyższenie wskaźnika rentowności } \\
\text { kapitału własnego (ROE), w porównaniu z sytuacją, w której przedsiębiorstwo jest } \\
\text { finansowane wyłącznie kapitałem własnym. }\end{array}$ \\
\hline R. Machała & $\begin{array}{l}\text { Dźwignia finansowa pozwala osiagnąć więcej niż proporcjonalny procentowy wzrost } \\
\text { zysku netto w przypadku wzrostu sumy zysku z działalności operacyjnej i przychodów } \\
\text { finansowych. }\end{array}$ \\
\hline $\begin{array}{l}\text { P. J. } \\
\text { Szczepankowski }\end{array}$ & $\begin{array}{l}\text { Przez dźwignię finansową rozumie się wpływ kosztów odsetek od kredytów i pożyczek } \\
\text { oraz zysku operacyjnego na efektywność wykorzystania kapitałów. }\end{array}$ \\
\hline M. Szudejko & $\begin{array}{l}\text { Dźwignia finansowa jest narzędziem wykorzystywanym przez przedsiębiorstwa do } \\
\text { podnoszenia ROE poprzez wykorzystanie } \\
\text { kapitałów obcych. }\end{array}$ \\
\hline T. Waśniewski & $\begin{array}{l}\text { Dźwignia finansowa wyraża strukturę kapitału i można ją zdefiniować jako użycie } \\
\text { niższego kosztu kapitału. }\end{array}$ \\
\hline D. Wędzki & $\begin{array}{l}\text { Dźwignia finansowa jest to zwielokrotnienie wyniku finansowego przypadającego na } \\
\text { kapitał własny na skutek zaangażowania kapitału obcego generującego odsetki } \\
\text { (odsetkowego). }\end{array}$ \\
\hline D. Zawadzka & $\begin{array}{l}\text { Zjawisko dźwigni finansowej wiaże się z wykorzystywaniem kapitału obcego w } \\
\text { strukturze finansowania przedsiębiorstwa. Dodatni efekt dźwigni finansowej polega na } \\
\text { zwiększaniu rentowności kapitałów własnych przez zastosowanie kapitałów obcych. }\end{array}$ \\
\hline
\end{tabular}

Źródło: opracowanie własne na podstawie: T. Berent: Ogólna teoria dźwigni finansowej, Oficyna Wydawnicza SGH w Warszawie, Warszawa 2013, s.66 - 67, Z. Bodie, R.C. Merton: Finanse, PWE, Warszawa 2003, s. 128, E.F. Brigham, J.F. Houston: Podstawy zarzqdzania finansami, t. 2, PWE, Warszawa 2005, s. 113, J. Czekaj, Z. Dresler Z.: Zarzqdzanie finansami przedsiębiorstw. Podstawy teorii, PWN, Warszawa 2001, s. 228, W. Dębski: Teoretyczne i praktyczne aspekty zarzqdzania finansami przedsiębiorstwa, PWN, Warszawa 2005, s. 160, A. Duliniec: Finansowanie przedsiębiorstwa, PWE, Warszawa 2007, s. 83-84, R. Machała: Praktyczne zarzqdzanie finansami firmy, PWN, Warszawa 2001, s. 316, P. J. Szczepankowski: Zarzqdzanie finansami przedsiębiorstwa. Podstawy teoretyczne, przyktady i zadania, Wyd. WSPiZ im. L. Koźmińskiego, Warszawa 2004, s. 185, T. Waśniewski: Analiza finansowa w przedsiębiorstwie, Fundacja Rozwoju Rachunkowości w Polsce, Warszawa 1997, s. 257, D. Wędzki: Analiza wskaźnikowa sprawozdania finansowego wedlug polskiego prawa bilansowego, Wolters Kluwer business, wyd. 3 zmienione, Warszawa 2015, s. 245, D. Zawadzka: Struktura kapitatu przedsiębiorstwa, [w:] Red. nauk. A. Bielawska: Nowoczesne zarzadzanie finansami przedsiębiorstwa, C.H. Beck, Warszawa 2009, s. 88

Z mechanizmem dźwigni finansowej łączy się kilka dodatkowych pojęć, służących dokładniejszemu przyjrzeniu się wpływowi jaki wywiera to zjawisko na finanse przedsiębiorstw. Są nimi m.in.: efekt dźwigni finansowej, stopień dźwigni finansowej, próg rentowności kapitału obcego. W realizacji celu niniejszego opracowania szczegółowego wyjaśnienia wymaga pojęcie efektu dźwigni finansowej. Niektórzy autorzy 
utożsamiają je po prostu z dźwignią finansową. Można jednak spotkać w literaturze różne sposoby skonkretyzowania tego pojęcia, co przedstawiono w Tabeli 2.

Tabela 2. Wybrane definicje efektu dźwigni finansowej

\begin{tabular}{|l|l|}
\hline \multicolumn{1}{|c|}{ Autor } & \multicolumn{1}{c|}{ Definicja } \\
\hline $\begin{array}{l}\text { J. Czekaj, } \\
\text { Z. Dresler }\end{array}$ & $\begin{array}{l}\text { Wraz ze wzrostem udziału kredytu bankowego wzrasta stopa zwrotu z kapitału własnego. } \\
\text { [...] Jest to dodatni efekt zjawiska dźwigni finansowej }\end{array}$ \\
\hline A. Duliniec & $\begin{array}{l}\text { Efekt działania dźwigni finansowej polega na tym, że w wyniku stałego obciążenia } \\
\text { kosztami finansowymi [...], możliwe wahania zysków przypadających na jedną akcję są } \\
\text { więcej niż proporcjonalne w stosunku do wahań zysku operacyjnego.[...] Efekty dźwigni } \\
\text { finansowej mogą być pozytywne, gdy przyczyniają się do wzrostu zysków przypadających } \\
\text { na jedną akcję lub negatywne, gdy powodują spadek zysków }\end{array}$ \\
\hline J. Ostaszewski & $\begin{array}{l}\text { Efekty dźwigni finansowej mogą być zarówno pozytywne, jak i negatywne. Efekty } \\
\text { pozytywne występują wtedy, kiedy stopa zysku (ROI) przewyższa stopę oprocentowania } \\
\text { kredytów (i) }\end{array}$ \\
\hline $\begin{array}{l}\text { R. Tuzinek, } \\
\text { M. Wrzesiński }\end{array}$ & $\begin{array}{l}\text { Wzrost rentowności kapitału własnego ponad rentowność kapitału ogółem, dzięki } \\
\text { zangażowaniu kapitału obcego, jest nazywany efektem działania dźwigni finansowej }\end{array}$ \\
\hline A. Żwirbla & $\begin{array}{l}\text { Dodatni (ujemny) efekt dźwigni finansowej występuje wówczas, gdy wzrost zadłużenia } \\
\text { podnosi (obniża) rentowność kapitałów własnych }\end{array}$ \\
\hline
\end{tabular}

Źródło: opracowanie własne na podstawie: J. Czekaj, Z. Dresler: Zarzqdzanie finansami przedsiębiorstw. Podstawy teorii, PWN, Warszawa 2001, s. 229, A. Duliniec: Struktura i koszt kapitału w przedsiębiorstwie, PWN, Warszawa 1998, s. 55, J. Ostaszewski: Źródła pozyskiwania kapitału przez spółkę akcyjnq, Difin, Warszawa 2000, s. 81, Red. nauk. L. Szyszko: Finanse przedsiębiorstwa, PWE, Warszawa 2000, s.141, A. Żwirbla: Nowe ujęcie rachunku dźwigni ekonomicznych. Produkcja jedno- $i$ wieloasortymentowa, PWN, Warszawa 2017, s. 77

Z powyższych definicji wynika, że oprocentowany dług w strukturze finansowania przedsiębiorstwa może działać albo na jego korzyść, czyli zwiększać rentowność kapitału własnego - mówimy wtedy o pozytywnym efekcie dźwigni finansowej, albo na niekorzyść podmiotu, a więc obniżać stopę zwrotu z kapitałów właścicieli, co nazywa się negatywnym efektem dźwigni finansowej (lub efektem maczugi finansowej).

$\mathrm{Z}$ punktu widzenia zarządzania finansami jednostki niezmiernie ważne jest, aby wiadomo było, kiedy korzystanie z zadłużenia jest dla przedsiębiorstwa opłacalne, a więc wpłynie na wzrost ROE, a kiedy zwiększanie udziału kapitałów obcych zadziała negatywnie na poziom stopy zwrotu z kapitałów właścicieli.

Warunkiem pozytywnego efektu dźwigni finansowej jest uzyskiwanie odpowiednio wysokiej rentowności operacyjnej majątku w stosunku do kosztu kapitału obcego. W celu sprawdzenia tego efektu sprawdza się nierówność:

$\frac{E B I T}{A}>r$ gdzie:

EBIT - zysk z działalności operacyjnej

A - aktywa

$\mathrm{r}$ - oprocentowanie długu (kapitału obcego).

W myśl powyższych zależności, przedsiębiorstwa osiagając rentowność operacyjna majątku na poziomie przekraczającym oprocentowanie długu, powinny, z punktu widzenia maksymalizacji ROE, zwiększać swoje zadłużenie poprzez zaciąganie kolejnych kredytów i pożyczek. 


\section{Możliwości stosowania pozytywnego efektu dźwigni finansowej w przedsiębiorstwach w Polsce w latach 2005-2018}

Kolejnym etapem badań było sprawdzenie czy przedsiębiorstwa w minionych 14 latach osiagały wystarczająco wysoką rentowność, aby przewyższała ona średnie oprocentowanie kredytów udzielanych przez banki komercyjne. Spełnienie tej zależności uzasadniałoby zwiększanie zadłużenia w bankach, a wręcz wskazywałoby, że takie decyzje byłyby słuszne, ponieważ prowadziłyby do osiagania wyższych stóp zwrotu dla właścicieli (ROE).

$\mathrm{Na}$ poniższym Rysunku 1 zestawiono dane na temat rentowności operacyjnej aktywów przedsiębiorstw w latach 2005-2018 oraz średnie oprocentowanie kredytów udzielanych przez banki komercyjne na cele gospodarcze. Oprocentowanie to obliczone zostało na podstawie danych z NBP o miesięcznych średnich oprocentowania kredytów złotowych oraz denominowanych w euro. Do obliczenia zastosowano średnią ważoną, biorąc pod uwagę udziały udzielanych kredytów złotowych oraz w euro.

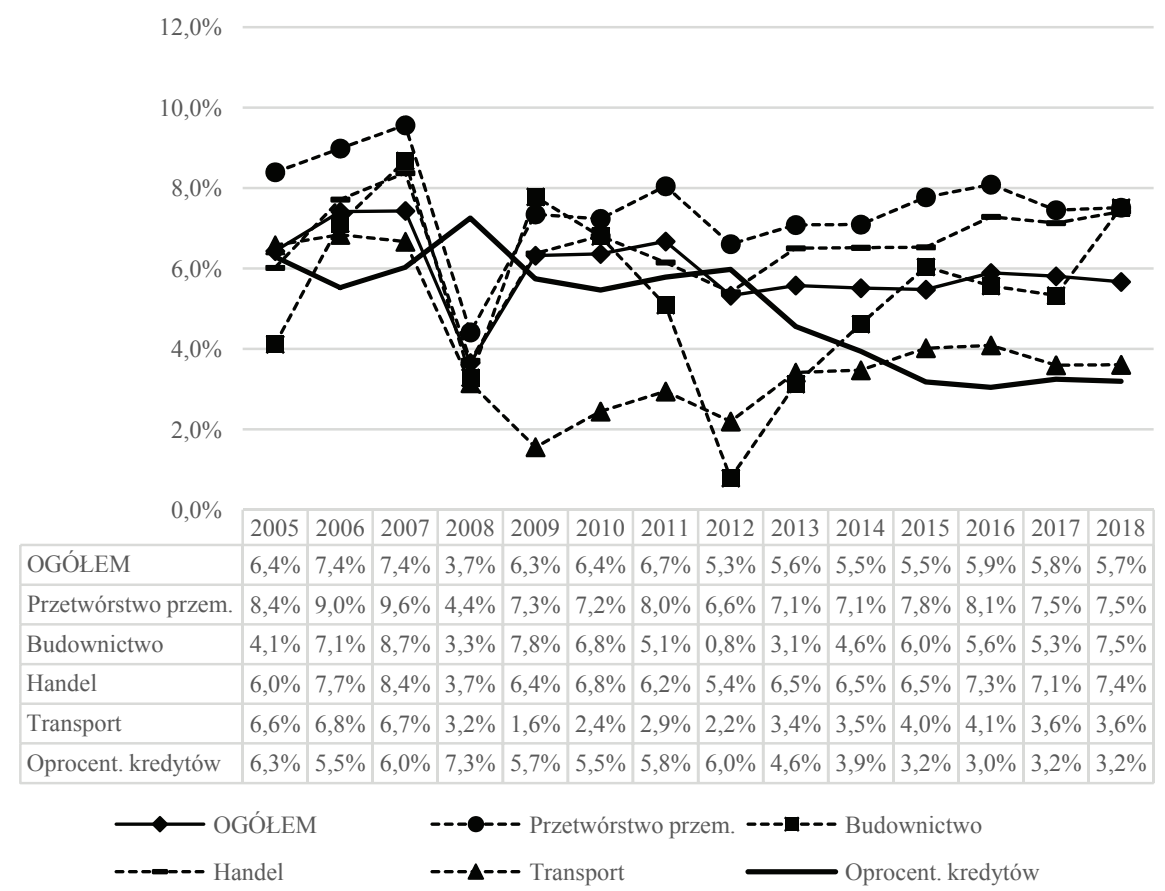

Rysunek 1. Rentowność operacyjna aktywów (EBIT/A) w przedsiębiorstwach w Polsce oraz średnie oprocentowanie kredytów w latach 2005-2018 (dane w \%)

Źródło: Źródło: opracowanie własne na podstawie danych NBP https://www.nbp.pl/home.aspx?f=/statystyka/pieniezna_i_bankowa/oprocentowanie.html oraz Wyniki finansowe podmiotów gospodarczych za lata 2005-2018, Główny Urząd Statystyczny, Warszawa, https://stat.gov.pl/obszary-tematyczne/podmioty-gospodarcze-wyniki-finansowe/przedsiebiorstwaniefinansowe/wyniki-finansowe-podmiotow-gospodarczych-i-xii-2018,11,20.html\#archive. 
Jak zauważyć można na powyższym wykresie, rentowność operacyjna majątku przedsiębiorstw ulegała sporym wahaniom $w$ badanych latach. Biorąc pod uwagę wszystkie firmy (OGÓŁEM) najwyższa rentowność uzyskiwana była w początkowym okresie, tj. w latach 2006-2007. W żadnym z kolejnych lat nie osiagnięto już tak wysokiego wyniku. Okresami stosunkowo wysokiej rentowności były jeszcze lata 2009 i 2011. Najniższe wyniki osiagnę̧y firmy w 2008 r. Było to jednoroczny, wyraźny spadek rentowności operacyjnej aktywów.

Podobnie jak w badaniu ogółu przedsiębiorstw kształtowała się rentowność firm należących do działu Przetwórstwo przemysłowe, co wynika $\mathrm{z}$ faktu, że to podmioty $\mathrm{z}$ tego działu są najliczniejszą i najistotniejszą zbiorowością przedsiębiorstw. Także firmy handlowe osiagały rentowność ulegającą podobnym fluktuacjom. Natomiast inaczej zachowywały się wskaźniki firm budowlanych oraz transportowych. $\mathrm{W}$ budownictwie najbardziej zwraca uwage gwałtowny spadek rentowności w latach 2011-2012.

Komentując kształtowanie się średniego oprocentowania kredytów dla przedsiębiorstw można stwierdzić, że wielkość ta sukcesywnie spadała w ostatnich 14 latach, chociaż miały także miejsce w tym czasie niewielkie wzrosty. Oprocentowanie kredytów wzrastało w latach 2007-2008 oraz także minimalnie w okresie 2011-2012.

Porównując poziom rentowności aktywów z oprocentowaniem, wyznaczone zostały lata, w których firmy mogły wykorzystywać pozytywny efekt dźwigni finansowej (Tabela 3.).

Tabela 3. Możliwość osiagnięcia pozytywnego efektu dźwigni finansowej w przedsiębiorstwach w Polsce w latach 2005-2018

\begin{tabular}{|c|c|c|c|c|c|c|c|c|c|c|c|c|c|c|}
\hline Sektor Lata & 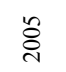 & ¿্ণ & ڤ్ & $\stackrel{\text { ¿ }}{\circ}$ & ڤ્ते & $\stackrel{\circ}{\stackrel{1}{*}}$ & $\overline{\vec{N}}$ & ָे & $\stackrel{m}{\stackrel{N}{N}}$ & $\stackrel{+}{\stackrel{\sim}{~}}$ & $\stackrel{n}{\grave{n}}$ & $\stackrel{\circ}{\circ}$ & $\overline{\bar{N}}$ & $\stackrel{\infty}{\stackrel{N}{\sim}}$ \\
\hline OGÓŁEM & $\mathrm{AK}$ & TAK & TAK & NIE & $\mathrm{AK}$ & TAK & TAK & NIE & TAK & TAK & TAK & TAK & TAK & TAK \\
\hline Przetw.przem & TAK & TAK & TAK & NIE & TAK & TAK & TAK & TAK & TAK & TAK & TAK & TAK & TAK & TAK \\
\hline Budownictwo & NIE & TAK & TAK & NIE & TAK & TAK & NIE & NIE & NIE & TAK & TAK & TAK & TAK & TAK \\
\hline Handel & NIE & TAK & TAK & NIE & TAK & TAK & TAK & NIE & TAK & TAK & TAK & TAK & TAK & TAK \\
\hline Transport & TAK & TAK & TAK & NIE & NIE & NIE & NIE & NIE & NIE & NIE & TAK & TAK & TAK & TAK \\
\hline
\end{tabular}

Źródło: opracowanie własne.

Dokonane obliczenia prowadzą do wniosku, że w analizowanym czternastoletnim okresie jedynie w 2008 oraz 2012 roku większość przedsiębiorstw nie miała wystarczająco wysokiej rentowności majątku, aby zwiększając zadłużenie uzyskiwać dodatni efekt dźwigni. W budownictwie do powyższych lat doszły jeszcze lata 2011 i 2013, a w firmach transportowych w całym okresie 2008-2014 nie był uzyskiwany taki poziom rentowności działalności, który przewyższałby koszt kredytów. Podkreślić jednak należy, że przez większość lat badanego okresu dla przedsiębiorstw korzystne byłoby zaciąganie nowych pożyczek i kredytów, ponieważ prowadziłoby to do wyższej stopy zwrotu dla właścicieli. 


\section{Analiza stopnia zadłużenia przedsiębiorstw z tytułu kredytów i pożyczek}

Kolejnym etapem przeprowadzonych badań była analiza stopnia zadłużenia przedsiębiorstw. Chciano $\mathrm{w}$ ten sposób sprawdzić, czy firmy $\mathrm{w}$ związku $\mathrm{z}$ osiąganą nadwyżką rentowności aktywów nad stopami oprocentowania kredytów bankowych, zwiększały udział finansowania tymi kapitałami. Obliczone zostały następujące wskaźniki:

- udział kredytów i pożyczek w pasywach,

- udział kredytów i pożyczek długoterminowych w pasywach,

- $\quad$ udział kredytów i pożyczek krótkoterminowych w pasywach.

Ich wartości oraz prezentacja graficzna przedstawiona została na poniższych wykresach (Rysunek 2, 3 i 4.).

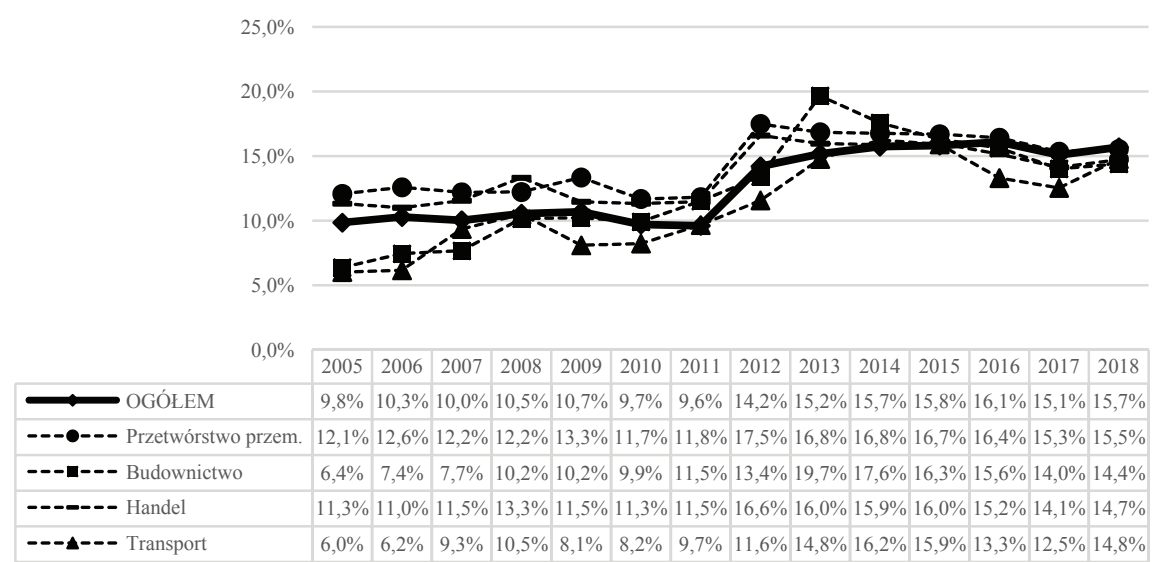

Rysunek 2. Udział kredytów i pożyczek razem w finansowaniu przedsiębiorstw w Polsce w latach 2005-2018 Źródło: opracowanie własne na podstawie Wyniki finansowe podmiotów gospodarczych za lata 2005-2018, Główny Urząd Statystyczny, Warszawa.

Komentując dane zawarte na powyższym rysunku należy przede wszystkim stwierdzić, że na przestrzeni analizowanych lat skala korzystania przedsiębiorstw z dłużnego finansowania zwiększyła się. Dotyczy to badania całej zbiorowości przedsiębiorstw oraz czterech najważniejszych działów gospodarki. Bardziej szczegółowa analiza tych danych wskazuje, że największy przyrost finansowania dłużnego (oprocentowanego) miał miejsce w 2012 r. W badaniu ogółu firm wyróżnić można dwa okresy, w których udział kredytów i pożyczek w finansowaniu nie zmieniał się znacząco, były to lata 2005-2011 oraz 2013-2018.

Kształtowanie się zakresu wykorzystywania długoterminowych kredytów i pożyczek w finansowaniu przedsiębiorstw było nieco inne. Okres intensywnego wzrostu wykorzystania tych kapitałów był dłuższy, trwał 3 lata, tj. 2012-2014.

Charakterystyczny jest także ponad dwukrotny wzrost udziału długu długoterminowego w 2013 r. w budownictwie. Po tym czasie jednak udział ten spadał już do końca badanego okresu. Ponadto warto zauważyć, że z racji specyfiki 
działalności, wyraźnie najmniejszy zakres wykorzystywania kredytów i pożyczek długoterminowych dotyczy firm handlowych.

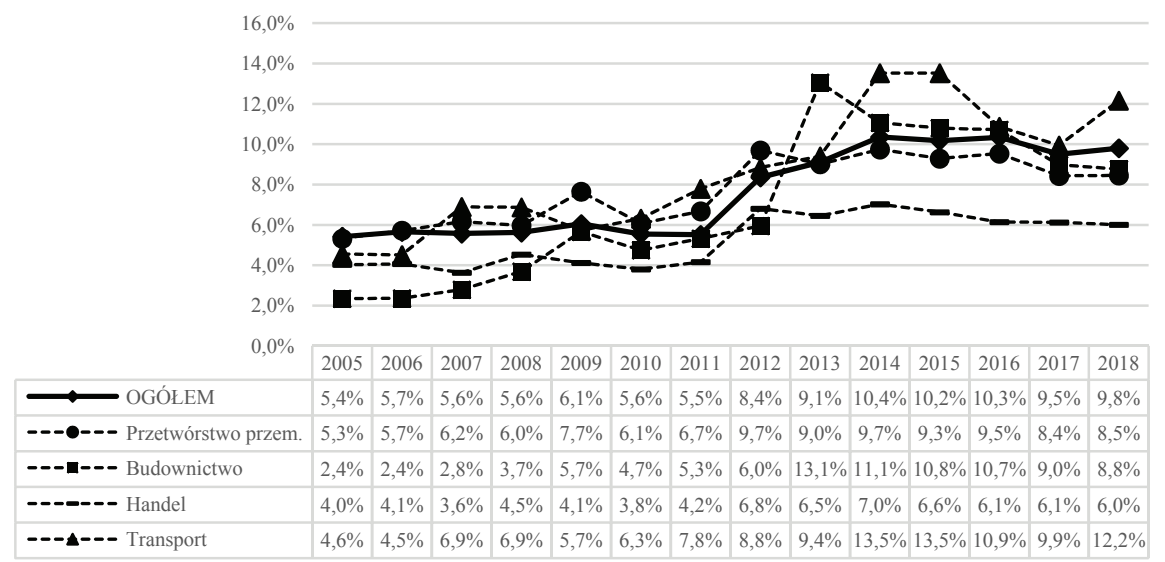

Rysunek 3. Udział kredytów i pożyczek długoterminowych w finansowaniu przedsiębiorstw w Polsce w latach 2005-2018

Źródło: opracowanie własne na podstawie danych Wyniki finansowe podmiotów gospodarczych za lata 20052018, Główny Urząd Statystyczny, Warszawa.

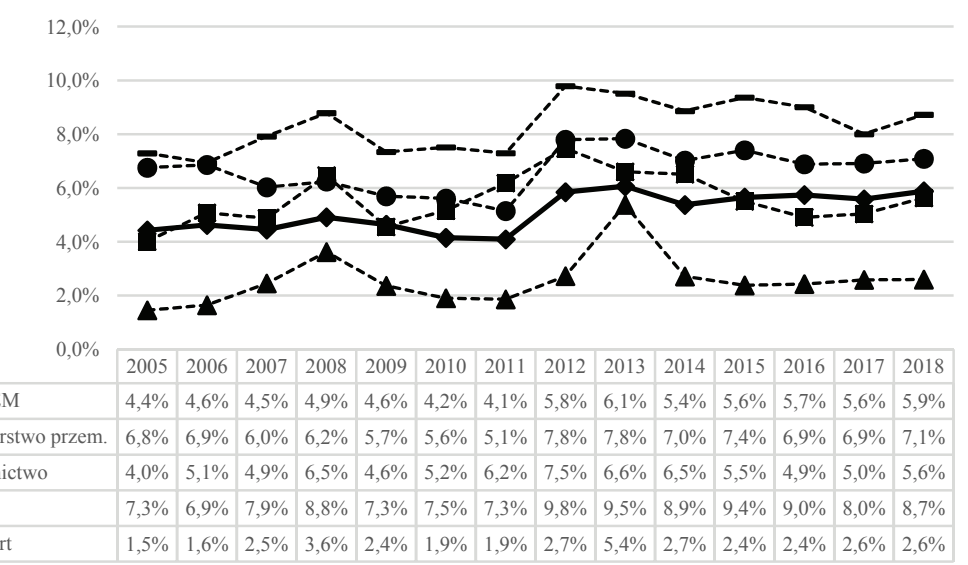

Rysunek 4. Udział kredytów i pożyczek krótkoterminowych w finansowaniu przedsiębiorstw w Polsce w latach 2005-2018

Źródło: opracowanie własne na podstawie danych Wyniki finansowe podmiotów gospodarczych za lata 20052018, Główny Urząd Statystyczny, Warszawa.

Zmiany skali korzystania przedsiębiorstw $\mathrm{z}$ krótkoterminowych kredytów i pożyczek były najmniejsze. We wszystkich badanych grupach firm widoczny jest wzrost udziału omawianych źródeł finansowania w 2012 r.

Stosunkowo duże zmiany udziału krótkoterminowego oprocentowanego długu miały miejsce w budownictwie. Widać tu największe zastosowanie tych zobowiązań w 2008 i 2012 r. Charakterystyczny jest także wzrost udziału w latach 2010-2012, 
a następnie spadek w kolejnych 4 latach. Warty zauważenia jest także jednoroczny wzrost zaangażowania omawianych źródeł finansowania w firmach transportowych w 2013.

\section{Badanie korelacji pomiędzy udziałem kredytów i pożyczek w finansowaniu przedsiębiorstw a nadwyżką rentowności operacyjnej aktywów nad oprocentowaniem kredytów bankowych}

W celu stwierdzenia czy działania przedsiębiorstw były racjonalne z punktu widzenia maksymalizacji rentowności kapitału własnego przy wykorzystaniu pozytywnego efektu dźwigni finansowej, obliczono wskaźniki korelacji liniowej Pearsona pomiędzy udziałem kredytów i pożyczek (długo-, krótkoterminowych i ogółem) w pasywach firm a różnicą pomiędzy rentownością operacyjną aktywów a średnim oprocentowaniem kredytów bankowych. To właśnie ta dodatnia różnica zapewnia działanie pozytywnego mechanizmu dźwigni.

W badaniu starano się także uwzględnić fakt, że struktura kapitału przedsiębiorstwa jest najczęściej trudna do zmiany w krótkim okresie i zarządzający mogą reagować na napływające informacje z pewnym przesunięciem czasowym. Chcąc więc uwzględnić ewentualne opóźnienia reakcji na osiagnięte nadwyżki rentowności nad oprocentowaniem kredytów, obliczono współczynniki korelacji bez opóźnień oraz przy zastosowaniu jednorocznego i dwuletniego opóźnienia. Obliczenia zostały dokonane osobno w stosunku do udziału wszystkich kredytów i pożyczek (razem) w pasywach przedsiębiorstw, jak również tych długo- i krótkoterminowych. Wyniki powyższego zamieszczono w poniższej tabeli.

Tabela 4. Badanie korelacji pomiędzy udziałem kredytów i pożyczek w pasywach a różnicą pomiędzy rentownością operacyjną aktywów a oprocentowaniem kredytów bankowych

\begin{tabular}{|c|c|c|c|c|c|c|c|}
\hline \multirow[b]{2}{*}{ Przedsiębiorstwa } & \multirow{2}{*}{$\begin{array}{c}\text { Udział } \\
\text { kredytów i } \\
\text { pożyczek }\end{array}$} & \multicolumn{2}{|c|}{ Bez opóźnień } & \multicolumn{2}{|c|}{ Roczne opóźnienie } & \multicolumn{2}{|c|}{ Dwuletnie opóźnienie } \\
\hline & & $\begin{array}{c}\text { Wsp. } \\
\text { korelacji }\end{array}$ & $\begin{array}{l}\text { Poziom } \\
\text { istotności }\end{array}$ & $\begin{array}{c}\text { Wsp. } \\
\text { korelacji }\end{array}$ & $\begin{array}{l}\text { Poziom } \\
\text { istotności }\end{array}$ & $\begin{array}{c}\text { Wsp. } \\
\text { korelacji }\end{array}$ & $\begin{array}{l}\text { Poziom } \\
\text { istotności }\end{array}$ \\
\hline \multirow{3}{*}{ Ogółem } & razem & 0,47 & $7,7 \%$ & 0,38 & $15,5 \%$ & 0,42 & $13,7 \%$ \\
\hline & długoterm. & 0,53 & $4,8 \%$ & 0,40 & $14,1 \%$ & 0,36 & $18,1 \%$ \\
\hline & krótkoterm. & 0,26 & $24,9 \%$ & 0,29 & $23,2 \%$ & 0,54 & $5,7 \%$ \\
\hline \multirow{3}{*}{ Przetw. przem. } & razem & 0,37 & $15,4 \%$ & 0,20 & $30,2 \%$ & 0,28 & $25,1 \%$ \\
\hline & długoterm. & 0,38 & $14,3 \%$ & 0,14 & $34,8 \%$ & 0,25 & $27,3 \%$ \\
\hline & krótkoterm. & 0,24 & $26,2 \%$ & 0,29 & $23,1 \%$ & 0,29 & $23,9 \%$ \\
\hline \multirow{3}{*}{ Budownictwo } & razem & 0,09 & $37,0 \%$ & $-0,23$ & $28,5 \%$ & $-0,15$ & $34,6 \%$ \\
\hline & długoterm. & 0,25 & $25,9 \%$ & $-0,20$ & $30,7 \%$ & $-0,14$ & $35,0 \%$ \\
\hline & krótkoterm. & $-0,56$ & $3,4 \%$ & $-0,18$ & $31,7 \%$ & $-0,06$ & $38,0 \%$ \\
\hline \multirow{3}{*}{ Handel } & razem & 0,28 & $23,0 \%$ & 0,34 & $18,5 \%$ & 0,32 & $21,2 \%$ \\
\hline & długoterm. & 0,40 & $12,9 \%$ & 0,35 & $17,8 \%$ & 0,35 & $18,8 \%$ \\
\hline & krótkoterm. & 0,10 & $36,8 \%$ & 0,29 & $22,7 \%$ & 0,24 & $27,7 \%$ \\
\hline \multirow{3}{*}{ Transport } & razem & 0,22 & $28,4 \%$ & 0,17 & $33,0 \%$ & $-0,04$ & $38,5 \%$ \\
\hline & długoterm. & 0,31 & $20,4 \%$ & 0,23 & $27,9 \%$ & $-0,06$ & $38,0 \%$ \\
\hline & krótkoterm. & $-0,19$ & $30,6 \%$ & $-0,15$ & $33,7 \%$ & 0,05 & $38,4 \%$ \\
\hline
\end{tabular}

Źródło: obliczenia własne na podstawie danych z Rysunków 1-4. 
Z tabeli wynika, że w niemal wszystkich analizowanych przypadkach nie ma związku (korelacji) pomiędzy możliwościami osiągania pozytywnego efektu dźwigni finansowej a zwiększaniem udziału długu w finansowaniu. W znakomitej większości obliczone wskaźniki są mniejsze od 0,4 , co świadczy o braku lub niskiej korelacji. Wskaźniki te nie są także istotne statystycznie.

Istotne statystycznie, dodatnie korelacje otrzymano jedynie w badaniu ogółu przedsiębiorstw w przypadku nie stosowania opóźnień czasowych (kredyty i pożyczki długoterminowe i ogółem) oraz przy dwuletnim opóźnieniu i kredytach krótkoterminowych. Trudno jednak logicznie i racjonalnie wyjaśnić te zależności. Zaobserwowanie $\mathrm{w}$ danym roku wyższej rentowności majątku niż oprocentowanie kredytów, nie będzie rzutować na zmianę skali wykorzystania kredytów, ogółem czy tym bardziej tych długoterminowych, od razu (w tym samym roku). Również reakcja dopiero po dwóch latach w udziale krótkoterminowych kredytów i pożyczek jest mało spodziewana.

Drugą istotną statystycznie korelację, ale o ujemnym znaku, zaobserwowano w budownictwie, w stosunku do kredytów krótkoterminowych. Trudno jednak uznać, że w tym przypadku reakcja zarządzających była przemyślana, tzn. decyzje o zaangażowaniu kredytów do finansowania firm budowlanych podejmowane były przy uwzględnianiu zjawiska dźwigni finansowej. Ujemna korelacja oznacza bowiem, że firmy zwiększają finasowanie kredytami krótkoterminowymi wtedy, kiedy jest to mniej opłacalne, czyli wraz ze zmniejszaniem się nadwyżki rentowności aktywów nad kosztem (oprocentowaniem) kredytów.

\section{Wnioski z przeprowadzonych badań}

Podejmując próbę syntezy wyników badań zaprezentowanych w artykule, można sformułować następujące wnioski:

- Przedsiębiorstwa W większości lat okresu 2005-2018 osiagały rentowność operacyjną aktywów wyższą niż oprocentowanie kredytów bankowych, mogły więc osiagać pozytywny efekt dźwigni finansowej. Jedynymi latami, w których rentowność ta była zbyt niska były lata 2008 i 2012.

- $\quad \mathrm{Z}$ powyższego wynika, że przedsiębiorstwa w celu podwyższania stopy zwrotu z kapitałów własnych powinny zwiększać zakres finansowania kredytami i pożyczkami.

- Analiza udziału kredytów i pożyczek w pasywach przedsiębiorstw pozwala stwierdzić, że zarówno ogół przedsiębiorstw jak i jednostki z czterech najważniejszych działów gospodarki zwiększył zakres wykorzystania tych kapitałów w finansowaniu działalności w całym badanych czternastoletnim okresie. Należy to uznać proces uzasadniony i racjonalny.

- $\quad$ Przyrost skali finansowania działalności przedsiębiorstw kredytami i pożyczkami następował jednak nierównomiernie. Największy wzrost miał miejsce w 2012 r., czyli okresie, w którym przedsiębiorstwa uzyskiwały rentowność operacyjną majątku na poziomie niższym niż oprocentowanie kredytów bankowych, czyli nie był spełniony wtedy warunek pozytywnego efektu dźwigni finansowej. Podobna sytuacja (choć wtedy nieco słabszy przyrost finansowania kredytami i pożyczkami) miała miejsce w 2008 r. Tak więc wzrosty udziału kredytów w tych latach należy 
uznać za niekorzystne dla przedsiębiorstw, takie, które obniżały stopę zwrotu z kapitałów własnych.

- Uwzględniając jednak opóźnienia czasowe (jednoroczne i dwuletnie) działania zarządzających w zakresie kształtowania optymalnej struktury finansowania można uznać za bardziej racjonalne i uzasadnione. Po latach $\mathrm{z}$ negatywnym efektem dźwigni, cześć badanych zbiorowości przedsiębiorstw w czasie 1-2 lat zmniejszały skalę zaangażowania kredytów (przetwórstwo przemysłowe, handel). Jednocześnie w budownictwie i transporcie zwiększano zadłużenie mimo niespełniania warunku pozytywnego efektu dźwigni finansowej.

- Badanie korelacji pomiędzy udziałem kredytów i pożyczek w pasywach przedsiębiorstw a nadwyżką (różnicą) rentowności operacyjnej aktywów nad oprocentowaniem kredytów bankowych doprowadziło do wniosku, że nie istnieje istotna statystycznie korelacja pomiędzy tymi wielkościami. Można więc uznać, że przedsiębiorcy w kształtowaniu struktury źródeł finansowania i podejmowaniu decyzji o zaangażowaniu oprocentowanego długu nie uwzględniają mechanizmu (efektu) dźwigni finansowej w celu zwiększania rentowności kapitałów własnych.

- Zarządzający mogą więc sugerować się w kształtowaniu struktury kapitału poziomem ryzyka lub względami pozafinansowymi (behawioralnymi).

\section{Podsumowanie}

Poszukiwanie optymalnej struktury źródeł finansowania przedsiębiorstw to od dziesięcioleci jeden $\mathrm{z}$ najczęściej podejmowanych problemów zarządzania finansami jednostek gospodarczych. Mechanizm i efekt dźwigni finansowej ściśle wiąże się z tym tematem. Dzięki tzw. pozytywnemu efektowi dźwigni finansowej przedsiębiorstwo może uzyskiwać wyższą stopę zwrotu z kapitału zaangażowanego przez jej właścicieli. Możliwe jest to dzięki zaangażowaniu oprocentowanego długu $\mathrm{w}$ finansowaniu.

W artykule wskazano, że w większości minionych czternastu lat przedsiębiorstwa w Polsce mogły wykorzystywać pozytywny efekt dźwigni finansowej, tzn. uzyskiwały taką zyskowność operacyjną zaangażowanego majątku, która przewyższała oprocentowanie kredytów i pożyczek udzielanych przez banki. Analiza źródeł finansowania wskazała, że przedsiębiorstwa generalnie zwiększyły w tych latach zakres kredytów i pożyczek w finansowaniu. Jednocześnie nie została stwierdzona oczekiwana na gruncie teoretycznym dodatnia (istotna statystycznie) korelacja pomiędzy nadwyżką rentowności aktywów nad kosztem długu a udziałem kredytów i pożyczek w pasywach.

Tak więc uwzględniając powyższe można uznać, że decyzje przedsiębiorstw o wykorzystywaniu oprocentowanych kapitałów obcych do finansowania nie były podejmowane przy uwzględnianiu efektu dźwigni finansowej. Należy więc sądzić, że decyzje te były podyktowane innymi czynnikami.

\section{Literatura:}

Berent T.: Ogólna teoria dźwigni finansowej, Oficyna Wydawnicza Szkoła Główna Handlowa w Warszawie, Warszawa 2013.

Berent T.: Ryzyko dźwigni finansowej - nowe podejście metodologiczne, Ekonomista 3/2011.

Bodie Z., Merton R. C.: Finanse, PWE, Warszawa 2003. 
Brigham E. F., Houston J. F.: Podstawy zarzadzania finansami, t. 2, PWE, Warszawa 2005.

Czekaj J., Dresler Z.: Zarzqdzanie finansami przedsiębiorstw. Podstawy teorii, PWN, Warszawa 2001.

Dębski W.: Teoretyczne i praktyczne aspekty zarzadzania finansami przedsiębiorstwa, PWN, Warszawa 2005.

Duliniec A.: Finansowanie przedsiębiorstwa, PWE, Warszawa 2007.

Duliniec A.: Struktura i koszt kapitatu w przedsiębiorstwie, PWN, Warszawa 1998.

Finanse przedsiębiorstwa, pod red. L. Szyszko, PWE, Warszawa 2000.

Kardyś M.: Dźwignia finansowa $w$ teorii i polskiej praktyce gospodarczej, BANK I KREDYT $3 / 2003$.

Kata R.: Korzystanie z kredytów bankowych przez mate i średnie przedsiębiorstwa $w$ Polsce, Zeszyty Naukowe SGGW w Warszawie, Ekonomika i Organizacja Gospodarki Żywnościowej $119 / 2017$.

Lucey B., MacAnBhaird C., Sanchez Vidal J.: Discouraged borrowers: Evidence for Eurozone SMEs, (April 3, 2016). JIFMIM, Forthcoming. Available at SSRN: https://ssrn.com/abstract $=2758338$.

Machała R.: Praktyczne zarzadzanie finansami firmy, PWN, Warszawa 2001.

Minton B. A., Wruck K. H.: Financial Conservatism: Evidence on Capital Structure from Low Leverage Firms (July 9, 2001). AFA 2002 Atlanta; Dice Ctr. Working Paper No. 2001-6. Available at SSRN: https://ssrn.com/abstract=269608. or http://dx.doi.org/10.2139/ssrn.269608.

Nowoczesne zarzqdzanie finansami przedsiębiorstwa, red. nauk. A. Bielawska, C.H. Beck, Warszawa 2009.

Ostaszewski J.: Źródła pozyskiwania kapitalu przez spótkę akcyjna, Difin, Warszawa 2000.

Statystyka stóp procentowych, Narodowy Bank Polski, https://www.nbp.pl/home.aspx?f=/statystyka/pieniezna i bankowa/oprocentowanie.html.

Stępień K.: Nadrzędne cele działalności jednostek gospodarczych, Zeszyty Naukowe Akademii Ekonomicznej w Krakowie, nr 674/2005.

Szczepankowski P. J.: Zarzadzanie finansami przedsiębiorstwa. Podstawy teoretyczne, przykłady $i$ zadania, Wydawnictwo Wyższej Szkoły Przedsiębiorczości i Zarządzania im. Leona Koźmińskiego, Warszawa 2004.

Szudejko M.: Strategie zerowej i obniżonej dźwigni finansowej w polskich przedsiębiorstwach giełdowych, Zeszyty Naukowe Uniwersytetu Szczecińskiego nr 854, „Finanse, Rynki Finansowe, Ubezpieczenia" nr 73/2015.

Waśniewski T.: Analiza finansowa w przedsiębiorstwie, Fundacja Rozwoju Rachunkowości w Polsce, Warszawa 1997.

Wędzki D.: Analiza wskaźnikowa sprawozdania finansowego wedtug polskiego prawa bilansowego, Wolters Kluwer business, wyd. 3 zmienione, Warszawa 2015.

Wyniki finansowe podmiotów gospodarczych za lata 2005-2018, Główny Urząd Statystyczny, Warszawa, https://stat.gov.pl/obszary-tematyczne/podmioty-gospodarcze-wynikifinansowe/przedsiebiorstwa-niefinansowe/wyniki-finansowe-podmiotow-gospodarczych-i-xii2018,11,20.html\#archive.

Zawadzka D.: Struktura kapitału przedsiębiorstwa, [w:] Nowoczesne zarzq̨dzanie finansami przedsiebiorstwa, red. nauk. A. Bielawska, C.H. Beck, Warszawa 2009.

Żwirbla A.: Nowe ujęcie rachunku dźwigni ekonomicznych. Produkcja jedno$i$ wieloasortymentowa, PWN, Warszawa 2017.

\section{Abstract}

The optimal structure of financing has been a frequent subject of research in corporate finance management for decades. Financial leverage and its effects are closely related to this topic. Thanks to the positive effect of financial leverage, a company may obtain a higher return on equity. The 
aim of this article is to present a practical approach to the financial leverage effect and to analyse whether decisions about the degree of credit and loans in the financing of enterprises were reasonable from the point of view of their impact on the return on equity. The analysis covered the years 2005-2018. The paper examines the question of whether enterprises in Poland had the opportunity to use debt to increase ROE. It also analyses whether decisions on the level of credit and loan within the capital structure were correlated with the level of the operating margin(s) of assets over the cost of debt, which is a requirement for a positive effect from financial leverage. It was shown that in the majority of the analysed years, enterprises could increase their return on equity by increasing their share of debt financing, but it was not known whether these decisions were made by taking into account the phenomenon and the leverage effect.

Key words: financial leverage, sources of financing, capital structure.

JEL Codes: G30, G32.

Informacje o autorze:

Dr Katarzyna Lach

Katedra Finansów Przedsiębiorstw

Uniwersytet Ekonomiczny w Krakowie

30-698 Lusina, ul. Górska 27a

e-mail: lachk@uek.krakow.pl

ORCID: 0000-0002-8403-339X 